\title{
ABNORMALITIES OF COPPER METABOLISM IN WILSON'S DISEASE AND THEIR RELATIONSHIP TO THE AMINOACIDURIA
}

\author{
BY A. G. BEARN AND H. G. KUNKEL
}

(From the Hospital of The Rockefeller Institute for Medical Research, New York, N. Y.)

(Submitted for publication September 2, 1953 ; accepted November 25, 1953)

In recent years an increasing amount of evidence has accumulated suggesting that Wilson's disease is a metabolic disorder associated with disturbances in copper and amino acid metabolism (1-8). The urinary excretion of copper and amino acids are now known to be increased in this disease $(2,3)$. The total plasma amino acids are not significantly raised $(4,8)$, and the serum copper concentration, originally considered to be normal or increased, has recently been shown to be decreased (5). A reduced level of serum copper oxidase activity in Wilson's disease has also been briefly reported (5). The findings of Holmberg and Laurell (9) indicated that oxidase activity in the serum is due to ceruloplasmin the major copper containing protein of serum. A deficiency of ceruloplasmin in Wilson's disease, using spectrophotometric and immunological techniques has also been demonstrated (7). A genetic analysis of a large group of patients with Wilson's disease has been reported separately and indicates the disease to be inherited in an autosomal recessive fashion (10).

The experiments to be described in this and a companion paper (11) were undertaken to investigate further the abnormalities in copper and amino acid metabolism in this disease and to correlate these findings with the clinical condition of the patient with emphasis upon the extent of hepatic and neurological involvement. A control group of patients suffering from various types of cirrhosis of the liver was also studied.

\section{MATERIAL AND METHODS}

All patients studied were admitted to the hospital. Twenty-four-hour urine samples were collected in acidcleaned vessels and stored at $+4^{\circ} \mathrm{C}$. Thymol crystals or chloroform $(6 \mathrm{ml}$.) and toluene $(6 \mathrm{ml}$.) were added as preservatives. Urinary alpha amino nitrogen was determined by the gasometric ninhydrin method of Van Slyke, MacFadyen, and Hamilton (12). The method of Brand, Harris, and Biloon (13) was used to detect qualitatively the presence of urinary cystine and was also employed as a screening procedure in a search for aminoaciduria in siblings of patients with Wilson's disease. Urinary glucose was estimated using the "Clinitest" 1 reagent, and venous blood sugar according to the method of Nelson (14).

Serum and urinary copper were estimated in duplicate by a slight modification of the method described by Eden and Green (15). Serum copper estimations were carried out in duplicate using $5 \mathrm{ml}$. samples; for urinary estimation of copper 15 or $20 \mathrm{ml}$. was normally used. The average difference between duplicate analyses of a sample containing $5 \gamma$ of copper was 0.24 per cent. The average difference between duplicates can be calculated from the formula $2 / \sqrt{\sigma}$ where $\sigma=$ S.D. When necessary, copper analyses on $1 \mathrm{ml}$. samples of serum were carried out with considerable accuracy using the micro modification of the same procedure (15).

Serum copper enzyme (ceruloplasmin) was estimated by the method of Holmberg and Laurell (9) employing paraphenylendiamine (p.p.d.) as substrate. Oxygen uptake was measured in a Warburg flask at $37^{\circ} \mathrm{C}$. The solution of p.p.d. containing $5 \mathrm{mg}$. per $\mathrm{ml}$. was brought to $\mathrm{pH} 6.0$ by the drop-wise addition of $1 \mathrm{~N} \mathrm{HCl}$. The $\mathrm{pH}$ was measured in a Beckman $\mathrm{pH}$ meter. One $\mathrm{ml}$. of the p.p.d. solution together with $1 \mathrm{ml}$. of acetate buffer of $\mathrm{pH}$ 6 was placed in the flask. Five-tenths $\mathrm{ml}$. of serum, dialyzed at $+4^{\circ} \mathrm{C}$. against acetate buffer ( $\mathrm{pH}$ 6.0) for twelve hours, was placed in the sidearm. On all occasions, a control sample using $0.5 \mathrm{ml}$. of distilled water was used to correct for the oxygen uptake of paraphenylendiamine which occurred in the absence of ceruloplasmin.

Electrophoretic separation of sera was carried out in a starch-supporting medium by a previously described method (16). Special precautions were taken to remove traces of copper by washing the starch with "Versene" 2 and by doubly distilling the water used for the buffer solution and the electrode vessels. The micro-copper procedure (15) was employed for analyses of the serum fractions displaced from the starch segments; $4 \mathrm{ml}$. of serum were fractionated in each case.

\section{CLINICAL MATERIAL}

Seventeen patients with Wilson's disease were studied and compared with 23 patients with cirrhosis and 12 normal subjects.

\footnotetext{
1 Ames Company, Inc., Elkhart, Indiana.

2 The Versene used was kindly supplied by Riker Laboratories, Inc., Los Angeles, California.
} 


\begin{tabular}{|c|c|c|c|c|c|c|c|c|c|c|c|c|c|c|c|c|c|}
\hline 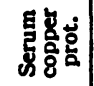 & की & 总 & $\underset{\substack{\infty \\
0}}{\stackrel{0}{0}}$ & 趈 & 怘 & ஃั & స్త్ర & 8 & 웡 & 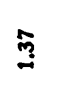 & : & & \&̊ & $\stackrel{\circ}{\circ}$ & & $\underset{\infty}{\mathbf{D}}$ & \& \\
\hline 影岕 & $\frac{8}{7}$ & in & 8 & $\infty$ & $z$ & $\approx$ & बे & $\hat{s}$ & $\ddot{n}$ & ః & 8 & I & N & $\approx$ & ธิ & 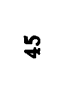 & 2 \\
\hline 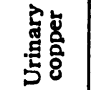 & 荬 & $\stackrel{\infty}{\infty}$ & 今े & 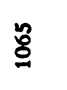 & $\stackrel{\sim}{\infty}$ & $\$$ & 3 & శ్లి & 足 & \$ & $\widehat{\hat{\sigma}}$ & & 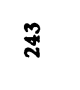 & 음 & ఖ్ల & జ్రి & జ్ర \\
\hline 空量 & & + & + & + & + & + & + & + & $\stackrel{+}{+}$ & $\stackrel{+}{+}$ & + & 0 & + & + & + & $\begin{array}{l}+ \\
+ \\
+\end{array}$ & $\begin{array}{l}+ \\
+ \\
+\end{array}$ \\
\hline$\frac{\vec{z}}{\overrightarrow{\underline{w}}}$ & & + & $\begin{array}{l}+ \\
+ \\
+\end{array}$ & $\begin{array}{l}+ \\
+\end{array}$ & + & + & + & + & $\stackrel{+}{+}$ & + & + & $\begin{array}{l}\infty \\
+\end{array}$ & + & 0 & + & + & + \\
\hline 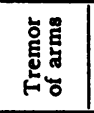 & & $\stackrel{+}{+}$ & + & + & + & + & + & $\begin{array}{l}+ \\
+ \\
+\end{array}$ & + & $\begin{array}{l}+ \\
+\end{array}$ & + & $\stackrel{\infty}{+}+$ & + & 0 & $\begin{array}{l}+ \\
+ \\
+\end{array}$ & $\stackrel{+}{+}$ & + \\
\hline 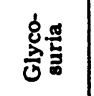 & & 0 & 0 & + & + & $\begin{array}{l}+ \\
+ \\
+\end{array}$ & + & 0 & $\begin{array}{l}+ \\
+ \\
+\end{array}$ & 0 & 0 & 0 & 0 & 0 & 0 & 0 & 0 \\
\hline 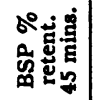 & & 9 & $\infty$ & 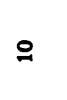 & 0 & $=$ & 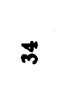 & + & $N$ & $\infty$ & $\cong$ & \& & 웅 & స్ల & 웅 & $\stackrel{\text { N }}{2}$ & $m$ \\
\hline 音泀 & $\begin{array}{l}80 \\
\dot{8}\end{array}$ & \pm & ò & $\dddot{m}$ & $\stackrel{\leftrightarrow}{0}$ & $\stackrel{\infty}{0}$ & $\stackrel{\circ}{i}$ & $\ddot{0}$ & $\hat{0}$ & $\stackrel{\infty}{0}$ & $\stackrel{\infty}{0}$ & 7 & $\stackrel{0}{0}$ & 9 & $\stackrel{0}{0}$ & $\stackrel{\circ}{\circ}$ & 苂 \\
\hline 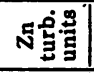 & & $\Phi$ & $\infty$ & 2 & $=$ & 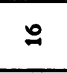 & 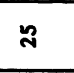 & 9 & $\mathscr{0}$ & $a$ & $a$ & & 9 & 9 & $=$ & 9 & $a$ \\
\hline$\stackrel{0}{4}$ & 5 & ?h & i & ${ }^{*} \mid m i$ & $\mid \stackrel{\infty}{i}$ & : & 蕉| & 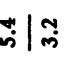 & $\left|\begin{array}{l}\infty \\
\dot{\sim}\end{array}\right| \bar{i}$ & 萬| & ن̊ & 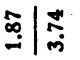 & พับ & il & $\vec{m} \mid \stackrel{m}{m}$ & 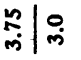 & $\mathfrak{i} \mid \vec{i}$ \\
\hline 解 & & 0 & 0 & 0 & 0 & 0 & + & 0 & 0 & 0 & 0 & \pm & & $\stackrel{+}{+}$ & 0 & 0 & 0 \\
\hline 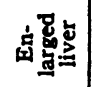 & & 0 & 0 & 0 & 0 & 0 & + & 0 & 0 & + & 0 & $\begin{array}{l}+ \\
+ \\
+\end{array}$ & 0 & $\begin{array}{l}+ \\
+ \\
+\end{array}$ & 0 & 0 & 。 \\
\hline 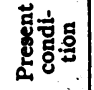 & & $\stackrel{0}{2}$ & $\stackrel{g}{z}$ & 焉 & $\stackrel{\square}{z}$ & $\stackrel{\stackrel{\partial}{4}}{4}$ & 苟 & $\stackrel{\stackrel{\Xi}{z}}{\&}$ & 苋 & $\stackrel{2}{\xi}$ & $\stackrel{\rightleftarrows}{\rightleftarrows}$ & घ̈ & $\stackrel{+}{\stackrel{z}{2}}$ & $\stackrel{\stackrel{3}{z}}{4}$ & $\stackrel{\frac{2}{2}}{\frac{2}{4}}$ & $\stackrel{\Xi}{Z}$ & $\stackrel{8}{\frac{2}{z}}$ \\
\hline 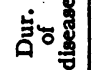 & $\dot{s}$ & $a$ & m & + & $n$ & $\stackrel{\infty}{=}$ & \pm & 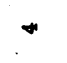 & $a$ & $m$ & n & - & + & 0 & - & $\bar{N}$ & $\vec{\pi}$ \\
\hline 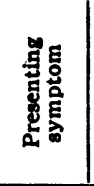 & & 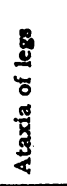 & 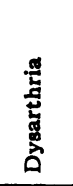 & 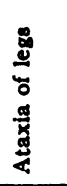 & 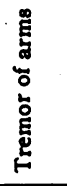 & 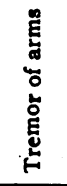 & 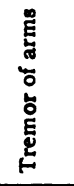 & 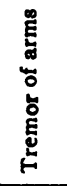 & 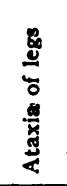 & 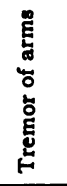 & 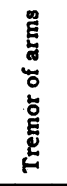 & 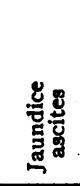 & 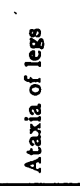 & 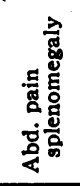 & 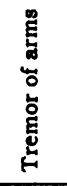 & 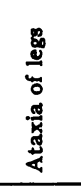 & 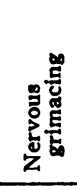 \\
\hline 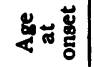 & $\dot{s}$ & $\bar{a}$ & $\stackrel{\circ}{\circ}$ & $=$ & $\hat{i}$ & ల్ల & 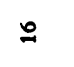 & i & $m$ & $\stackrel{\infty}{\sim}$ & ลे & $=$ & 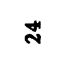 & $\simeq$ & 品 & 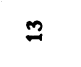 & $m$ \\
\hline 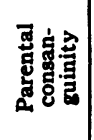 & & 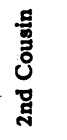 & 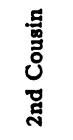 & 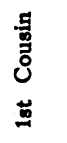 & 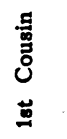 & 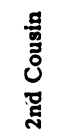 & 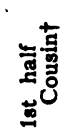 & $\overline{\bar{z}}$ & $\bar{z}$ & 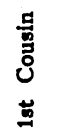 & 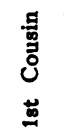 & $\bar{z}$ & $\bar{z}$ & 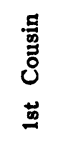 & $\vec{z}$ & 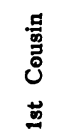 & $\begin{array}{l}\frac{a}{5} \\
\vec{b} \\
0 \\
\underline{\underline{a}}\end{array}$ \\
\hline 童品高 & & 苞 & 喤 & 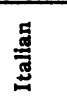 & 这 & 竜 & 흔 & 选啇 & 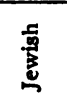 & 总 & $\stackrel{\text { 兽 }}{\mathrm{s}}$ & 䔍 & 总 & 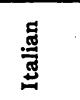 & 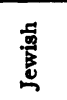 & 歖 & 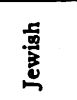 \\
\hline 8 & & $\omega$ & $\Sigma$ & $\Sigma$ & $\Sigma$ & $z$ & $\Sigma$ & $\Sigma$ & $\Sigma$ & $\Sigma$ & 4 & $\Sigma$ & 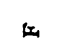 & $\Sigma$ & $\Sigma$ & is & is \\
\hline 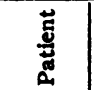 & & نُ & $\stackrel{\dot{\alpha}}{>}$ & $\stackrel{\dot{\Sigma}}{\dot{n}}$ & $\overrightarrow{0}$ & ¿ & $\begin{array}{l}\dot{3} \\
\dot{3}\end{array}$ & ن & $\begin{array}{l}\dot{0} \\
\dot{\alpha}\end{array}$ & $\begin{array}{l}\dot{0} \\
\dot{\Sigma}\end{array}$ & $\begin{array}{l}ن \\
0 .\end{array}$ & $\stackrel{\leftrightarrow}{\dot{m}}$ & $\dot{\dot{s}}$ & $\underset{\dot{H}}{\dot{\Sigma}}$ & $\stackrel{4}{\dot{z}}$ & $\begin{array}{l}* \\
\stackrel{\alpha}{\alpha} \\
\dot{\nu}\end{array}$ & 䓵 \\
\hline$\dot{\mathbf{z}}$ & & - & $N$ & m & + & $n$ & 0 & N & $\infty$ & $a$ & 9 & $=$ & $\simeq$ & $m$ & $\Xi$ & $\cong$ & 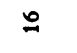 \\
\hline
\end{tabular}


TABLE II

Comparison of serum copper, serum copper enzyme (ceruloplasmin) and urinary copper in normal subjects, patients with cirrhosis of the liver and Wilson's disease*

\begin{tabular}{|l|c|c|c|}
\hline & $\begin{array}{c}\text { Normals } \\
{[12]}\end{array}$ & $\begin{array}{c}\text { Cirrhosis } \\
{[23]}\end{array}$ & $\begin{array}{c}\text { Wilson's Disease } \\
{[17]}\end{array}$ \\
\hline $\begin{array}{c}\text { Serum copper } \\
\mu \mathrm{g} . / 100 \mathrm{ml} .\end{array}$ & $\begin{array}{c}108 \pm 9.8 \\
{[11]}\end{array}$ & $171 \pm 47$ & $60 \pm 15.4$ \\
{$[20]$} & {$[17]$} \\
$\begin{array}{c}\text { Serum "copper enzyme" } \\
\mu \mathrm{M} . \text { oxygen uptake/ } \\
\text { ml./hr. }\end{array}$ & $\begin{array}{c}3.60 \pm 0.73 \\
{[12]}\end{array}$ & $\begin{array}{c}6.68 \pm 2.39 \\
{[18]}\end{array}$ & $\begin{array}{c}0.90 \pm 0.54 \\
{[15]}\end{array}$ \\
$\begin{array}{c}\text { Urinary copper } \\
\mu \mathrm{g} . / 24 \mathrm{hrs} .\end{array}$ & $\begin{array}{c}4 \pm 16.3 \\
{[11]}\end{array}$ & $\begin{array}{c}157.4 \pm 125.6 \\
{[18]}\end{array}$ & $\begin{array}{c}703 \pm 318 \\
{[16]}\end{array}$ \\
\hline
\end{tabular}

[ ]No. of cases

*.Mean values with_standard_deviations are recorded.

The patients with Wilson's disease had varying degrees of hepatic and neurological involvement (Table I). The predominance, in the affected group, of males and of patients of Jewish and Italian extraction, has been discussed in a previous paper (10).

The patients with cirrhosis included 12 suffering from nutritional Laënnec's cirrhosis, 4 with biliary cirrhosis, and a group of 7 young girls with severe liver disease of uncertain etiology which has previously been described (17).

\section{RESULTS}

\section{Serum copper}

The serum copper levels found in normal subjects, in patients with Wilson's disease and in patients suffering from cirrhosis of the liver are shown in Table II. It will be seen that the mean copper concentration in the serum of patients with Wilson's disease was considerably lower than that found in normal subjects, although in one patient the serum copper concentration was in the normal range. ${ }^{3}$ The wide scatter shown for the values obtained for the patients with cirrhosis may be a result of the heterogeneity of the clinical material. The mean serum copper concentration in the three varieties of cirrhosis studied is shown in Table III. The patients with nutritional Laennnec's cirrhosis did not show a serum copper concentration greatly in excess of normal, while those with biliary cirrhosis had high levels. Patients with cirrhosis of

8 An additional case has since been studied and a normal serum copper concentration found. the liver of unknown etiology occupied an intermediate position.

\section{Serum copper enzyme}

The serum copper enzyme (ceruloplasmin) was measured in the three groups studied and the results are illustrated in Table II. A striking decrease in oxidase activity was noted in all patients with Wilson's disease, while an increase in activity was noted in patients with cirrhosis of the liver. Table III illustrates the results obtained when the patients with cirrhosis of the liver are further classified. The greatest activity was again found to occur in the patients with biliary cirrhosis. Those with nutritional cirrhosis had an oxidase activity only slightly greater than normal, and those patients with cirrhosis of unknown etiology again occupied an intermediate position.

A parallelism between the serum copper concentration and the oxidase activity was first shown by Holmberg and Laurell (9). Figure 1 illustrates the parallelism in normal subjects, patients with cirrhosis of the liver and patients with Wilson's disease. The intercept of the regression line drawn to fit the experimental points suggests that in serum some copper is present which is not bound as ceruloplasmin and hence is not enzymatically active. In patients with Wilson's disease the ceruloplasmin activity appears to be somewhat less than would be expected from a consideration of the se- 
TABLE III

Comparison of serum copper, serum copper ensyme and urinary copper in various types of cirrhosis of the liver

\begin{tabular}{|c|c|c|c|}
\hline & $\begin{array}{c}\text { Laénnec } \\
{[10]}\end{array}$ & $\begin{array}{l}\text { *Undetermined } \\
\text { etiology } \\
{[8]}\end{array}$ & $\begin{array}{c}\text { Biliary } \\
{[5]}\end{array}$ \\
\hline $\begin{array}{l}\text { Serum copper } \\
\mu \mathrm{g} . / 100 \mathrm{ml} .\end{array}$ & $\begin{array}{c}142 \pm 8.0 \\
{[8]}\end{array}$ & ${ }_{[8]}^{163 \pm .1}$ & $\begin{array}{c}245 \pm 18.9 \\
{[4]}\end{array}$ \\
\hline $\begin{array}{l}\text { Serum "copper enzyme" } \\
\mu M \text { oxysen uptake/ml./hr. }\end{array}$ & $\begin{array}{c}5.46 \pm 2.14 \\
{[6]}\end{array}$ & $6.22 \pm 1.46$ & $9.45 \underset{[4]}{ \pm} 2.78$ \\
\hline $\begin{array}{l}\text { Urinary copper } \\
\mu g . / 24 \text { hrs. }\end{array}$ & ${ }_{[9]}^{86.2 \pm 48.4}$ & ${ }_{[7]}^{174.7} 62.8$ & $\begin{array}{l}269 \\
565 \\
{[2]}\end{array}$ \\
\hline
\end{tabular}

[ ] No. of cases.

Cirrhosis of the liver, occurring chiefly in young girls.

rum copper concentration, indicating that the nonceruloplasmin copper may be relatively increased.

In an attempt to evaluate the significance of the enzyme activity measured above and to study the distribution of copper among the various serum proteins, analyses of copper and enzyme activity were carried out on fractions of serum separated electrophoretically in a starch supporting medium. Difficulties were encountered because of the inability to prevent completely interference by traces of contaminating copper. In each experiment more copper was found on adding up the values obtained for each electrophoretic segment than was present in the original serum. Most of the contaminating copper became attached to the albumin fraction, a fact that was apparent in repeated experiments with the same serum. The height of the albumin peak was reduced under conditions where extreme

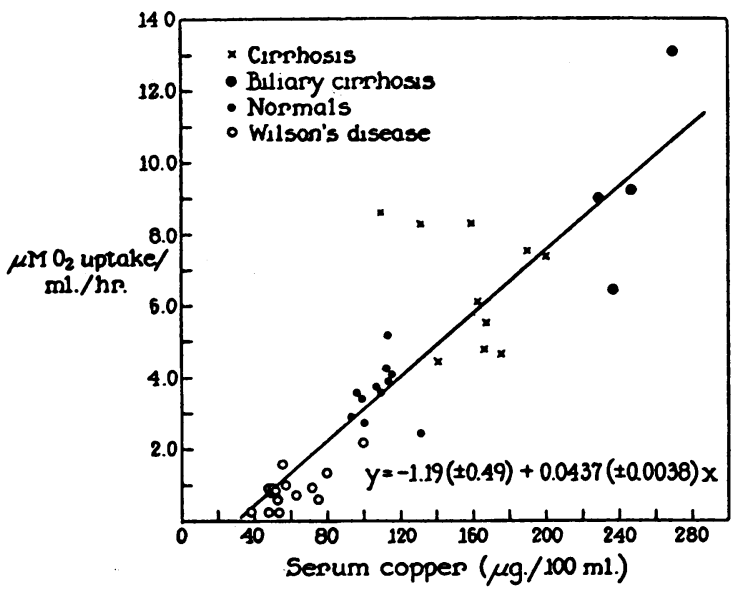

Fig. 1. The Relationship between the Serum Copper Concentration and Serum Copper Enzyme (Ceruloplasmin) care was exerted to exclude contaminating copper. To accomplish this end purified human albumin was applied to the starch block in front of the serum and this albumin picked up copper while the albumin in the serum became less contaminated. Figure 2 illustrates typical results obtained from a large number of sera of the three types tested for copper distribution. The curve obtained for protein in the same electrophoretic segments used for the copper analyses is illustrated for the normal serum. Two major copper peaks are visible, a front peak (dotted) representing the copper at the albumin, and a middle peak in the $\alpha_{2}$ globulin region. Determination of oxidase activity in the various fractions showed that all the activity was associated with the $\alpha_{2}$ globulin copper peak, which therefore represents ceruloplasmin. In some experiments a blue band against the white starch background could be seen in this region. The serum from the patient with Wilson's disease showed almost complete absence of the $\alpha_{2}$ globulin copper peak. In the case of cirrhosis, on the other hand, both this peak and the oxidase activity of the whole serum, were higher than normal.

The significance of the other small peaks is uncertain because of difficulty in defining exactly the baseline. The height of the $\alpha_{2}$ globulin copper peak showed very little variation from one experiment to another on the same serum in contrast to the variability of the copper peak in the albumin fraction. In addition, recovery experiments indicated that close to the total copper of the serum from normal individuals and patients with cirrhosis of the liver could be accounted for in this peak. Whether any of the copper found in 
the albumin fraction was non-contaminating copper was not clear from these experiments. In the sera of patients with Wilson's disease, the recovery experiments indicated that the low $\alpha_{2}$ globulin copper peak accounted for less of the total serum copper than in normal subjects and patients with cirrhosis of the liver. Studies with radioactive copper have shown final localization of radioactivity in the $\alpha_{2}$ globulin fraction after oral administration in normal individuals. The latter results confirm the localization of copper in this fraction found in the direct determinations of copper in the electrophoretic fractions.

\section{Urinary copper}

Urinary excretion of copper was greatly increased in all patients with Wilson's disease and was slightly increased in most patients with cirrhosis of the liver. These results are illustrated in Tables II and III. Although the highest values were obtained from patients with Wilson's disease, some overlap occurred with patients suffering from biliary cirrhosis. Under standard dietary conditions, day-to-day fluctuations in the urinary ex-

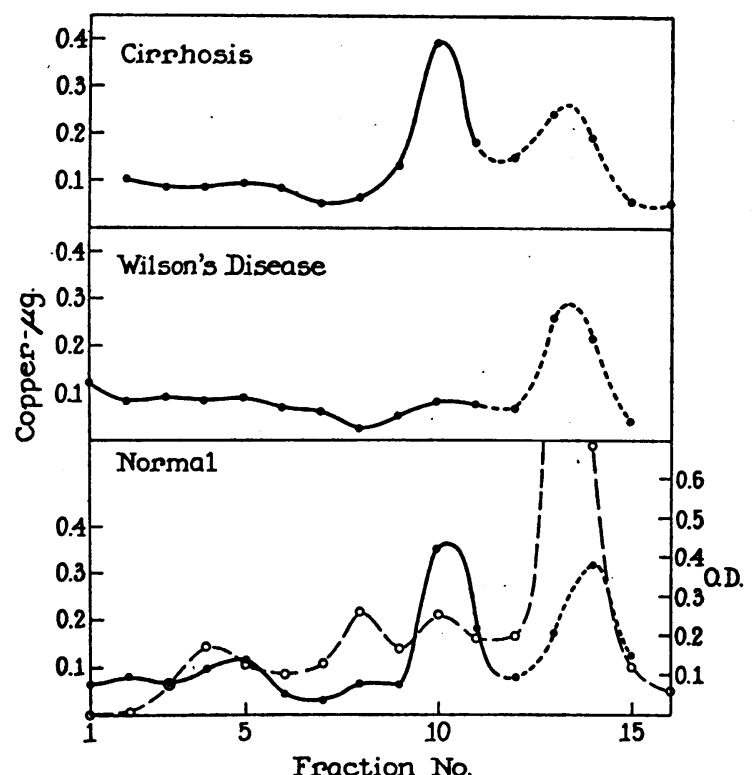

Fig. 2. Curves Showing the Distribution of Copper in Various Serum Fractions Separated by Zone ELECTROPHORESIS

The protein pattern is illustrated for the normal serum. The ceruloplasmin peak is in fraction 10. The broken line largely represents contaminating copper in the albumin fractions.

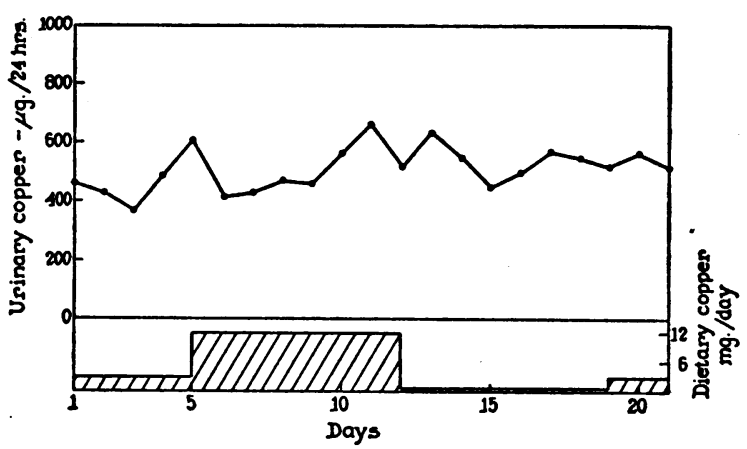

Fig. 3. The Effect of Dietary Copper Intake on the Urinary Excretion of Copper in Wilson's Disease

cretion of copper in all groups studied were found to be relatively small and to be independent of urinary volume.

\section{Amino acids}

Urinary excretion of alpha amino nitrogen was increased in 16 of the 17 cases of Wilson's disease. On a fixed protein diet, urinary excretion of alpha amino nitrogen of individual patients with Wilson's disease showed little day-to-day fluctuations, and was independent of urinary volume. Random samples of urine from 35 unaffected siblings of patients with Wilson's disease were examined and no significant aminoaciduria was detected in any of the cases studied, nor was consistent aminoaciduria found in patients with cirrhosis of the liver. Patients in hepatic coma were not tested.

\section{Glycosuria}

Glycosuria was found in 5 of the 17 patients with Wilson's disease and in these patients some correlation was noted between urinary glucose and urinary amino acid excretion. In addition, a rise in the amino acid excretion was often accompanied by an increased urinary excretion of glucose. In four of the five cases blood sugar determinations were carried out and showed that the fasting blood sugar was not elevated.

\section{Spectrographic analysis *}

Spectrographic analysis of the urine was carried out in one patient with Wilson's disease and one

4 Spectrographic analysis was carried out through the courtesy of Dr. R. O. Roblin, Jr., American Cyanamid Company. 


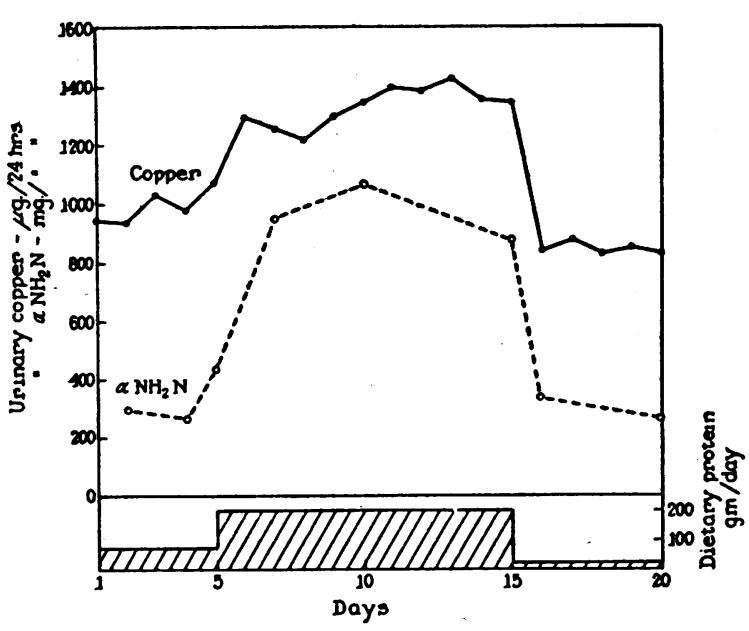

Fig. 4. The Effect of Variations in the Dietary Protein on the Urinary Excretion of Copper aNd Amino Acids in a Patient (L. A.) with Wilson's Disease

normal subject to study the excretion of other trace metals in Wilson's disease. Only the excretion of copper was found to be increased. The levels of iron, cobalt, nickel, and zinc were within normal limits.

\section{Relation of urinary copper and amino acid excre- tion to dietary intake of copper and protein}

Urinary excretion of copper in normal subjects and in patients with Wilson's disease was largely independent of copper intake. Thus, increasing the intake of copper from $0.5 \mathrm{mg}$. per day to 12 mg. per day did not result in a significant increase

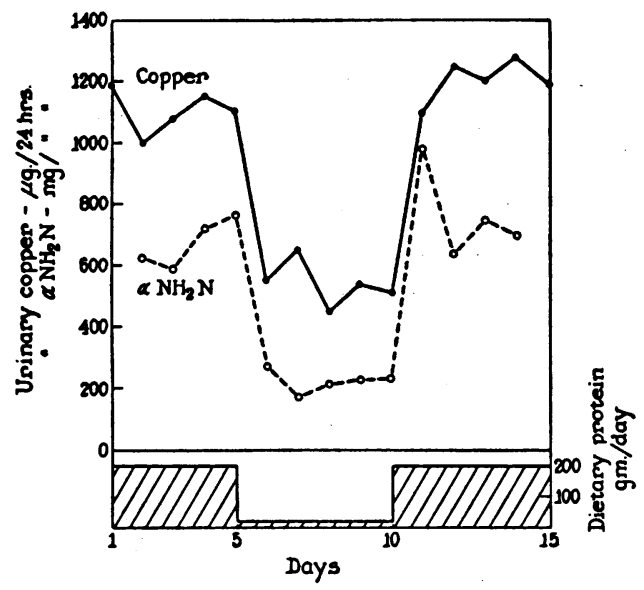

Fig. 5. Changes in the Urinary Copper and Amtno Acid Excretion Following Changes in Dietary Protein in Patient (C. P.) with Wilson's Disease

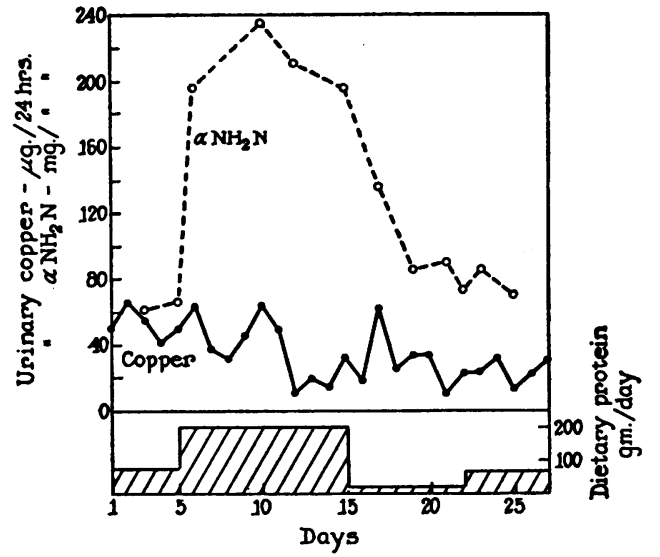

Fig. 6. Effect of Dietary Protein on Urinary Excretion of Copper and Amino Acids in a Normal SUBJECT

in the urinary excretion of copper (Figure 3 ). This result was found whether copper in the diet was increased or came from added copper sulfate. In patients with Wilson's disease an increased protein intake resulted in a prompt and parallel increase in the urinary excretion of copper and amino acids. The changes produced in two different patients are illustrated in Figures 4 and 5. In normal subjects increasing the dietary protein caused no detectable rise in the urinary excretion of copper. A typical response is shown in Figure 6.

The excess amino acids excreted in patients with Wilson's disease placed on a high protein diet were greater than occurred in normal subjects on the same diet. Both groups were placed on a 200 $\mathrm{Gm}$. protein diet and the total increased daily excretion of amino nitrogen in Wilson's disease was approximately three times more than occurred in normal subjects.

\section{Effect of cortisone, "Benemid", and mercurial diuretics}

The relationship between urinary copper and urinary amino acids in Wilson's disease was further demonstrated by the administration of cortisone. The increase in the amino acid excretion in Wilson's disease which followed the administration of cortisone was again promptly accompanied by a parallel increase in the urinary excretion of copper (Figure 7).

\footnotetext{
${ }^{8}$ p-[di-n-propylsulphamyl]-benzoic acid.
} 


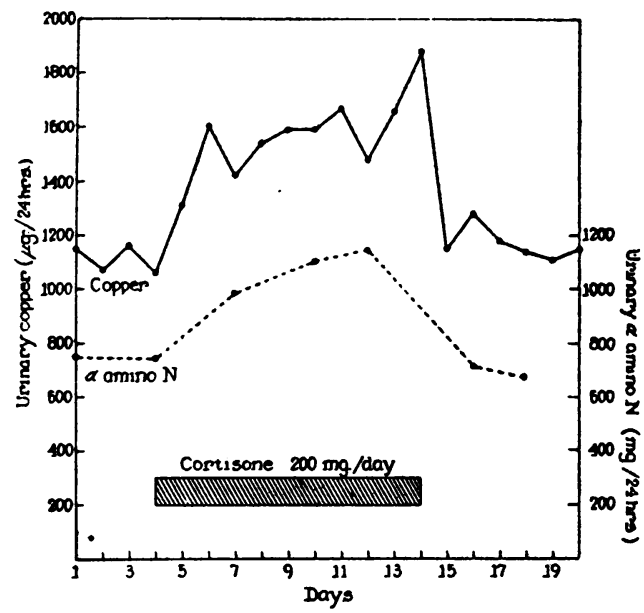

Fig. 7. Efrect of Cortisone on Urinary Excretion of Copper and Amino Acids in a Patient with WilSON's DISEASE

Mercurial diuretics and "Benemid" administered in full doses to two patients were not found to influence the excretion of amino acids in Wilson's disease significantly. Mercurial diuretics had no effect on the urinary excretion of copper. Following the administration of Benemid, however, there appeared to be a slight increase in the urinary excretion of copper in one patient.

\section{Effect of chelating agents}

The administration of BAL increased the urinary excretion of copper in all patients to whom it was given (Table IV). This was related to the amount of BAL given since increasing the dose increased the urinary excretion of copper.

TABLE IV *

The effect of various substances on urinary excretion of copper in Wilson's disease

\begin{tabular}{lccc}
\hline \multicolumn{1}{c}{ Compound } & Dose & $\begin{array}{c}\text { No. of } \\
\text { patients }\end{array}$ & $\begin{array}{c}\text { Mean } \\
\text { increase } \\
\text { per 24 hr. }\end{array}$ \\
\hline BAL & $2.5 \mathrm{mg} \cdot / \mathrm{Kg}$. & 9 & $\%$ \\
$\begin{array}{l}\text { Versene } \\
\text { (Intravenously) }\end{array}$ & $1 \mathrm{Gm}$. & 1 & 51 \\
$\begin{array}{l}\text { Versene } \\
\text { (Orally) }\end{array}$ & $30 \mathrm{Gm}$. & 3 & 138 \\
Cortisone & $100 \mathrm{mg}$. & 3 & 5 \\
& $200 \mathrm{mg}$. & 3 & 31 \\
\hline
\end{tabular}

* Figures represent mean values obtained during period of maximum effect.
"Versene" (20 per cent solution of calcium disodium salt of ethylenediaminetetracetic acid in $500 \mathrm{ml}$. of normal saline) was administered intravenously to patients with Wilson's disease. In all cases an increase in the urinary excretion of copper was noted and the mean results are shown in Table IV. Increasing the amount of "Versene" administered again increased the urinary excretion of copper. "Versene" administered orally (Table IV) did not increase the urinary excretion of copper significantly in the doses used. The daily urinary excretion of alpha amino nitrogen was not altered by the administration of BAL or "Versene".

The increased urinary excretion following the administration of BAL or intravenous "Versene" was independent of the degree of hepatic or neurological involvement.

\section{DISCUSSION}

The low serum copper concentration in $16^{\circ}$ of 17 patients with Wilson's disease confirms earlier work from this laboratory (5). Recently, Lahey, Gubler, Cartwright, and Wintrobe (18) have reported three additional patients with Wilson's disease who had a low concentration of copper in the serum. In patients with cirrhosis of the liver, on the other hand, the serum copper is frequently elevated. It has been shown by van Ravesteyn that copper is normally excreted in the bile (19). This observation is in agreement with the present finding that the degree of elevation of the serum and urinary copper in patients with cirrhosis is due at least in part to the degree of biliary obstruction associated with the cirrhotic process. $\mathrm{Pa}$ tients with classical nutritional Laennnec's cirrhosis without significant biliary obstruction have normal or slightly elevated serum copper and urinary copper concentrations while the higher values encountered in both serum and urine were those occurring in patients with biliary cirrhosis.

The greater part of the circulating serum copper is bound to a protein exhibiting oxidase activity. This protein has been called ceruloplasmin by Holmberg and Laurell (9). Ceruloplasmin has recently been measured by Scheinberg and Gitlin (7) using specific immunochemical techniques and also spectrophotometrically. They re-

6 See footnote 3 . 
ported eight patients with Wilson's disease in whom the ceruloplasmin concentration was considerably lower than normal and this finding is in accord with the results of the present study. Holmberg and Laurell (9) were the first to suggest that there was a parallelism between the concentration of copper in the serum and the oxidase activity. Further light on the relation of serum copper to various serum proteins has been derived from the experiments using zone electrophoresis. The major copper peak in normal serum and in the serum from patients with cirrhosis appeared in the $\alpha_{2}$ globulin region. The latter peak was markedly depressed in the sera of patients with Wilson's disease. The electrophoretic experiments also confirmed the specificity of the oxidase measurements of whole serum as an index of its ceruloplasmin level. Copper bound to other proteins in serum gave no enzymatic activity with the substrates employed.

The present work does not suggest that the main copper protein in serum (ceruloplasmin) functions as a transport mechanism in serum in a manner similar to the iron binding protein. This possibility was also considered unlikely by Gubler, Lahey, Cartwright, and Wintrobe (20) who have shown that following the oral ingestion of copper there is no change in the "indirect reacting" copper. It is probable that "indirect reacting" copper represents ceruloplasmin. The possibility of an enzymatic function in the body must be considered, particularly in view of the broad distribution of copper enzymes in tissues and the activity exhibited by this protein with synthetic substrates. Whether a deficiency of ceruloplasmin represents the primary genetically determined abnormality in Wilson's disease remains to be determined.

Preliminary observations suggested that there was a parallelism between the excretion of copper and the excretion of amino acids in patients with Wilson's disease (5). This observation was supported and amplified by the recent findings of Matthews, Milne, and Bell (8) who showed that ingestion of amino acids led to a prompt rise in the urinary excretion of copper and by the present work where increases in dietary protein gave rise to an increased excretion of copper and amino acids in the urine. In normal subjects, despite an increase in the urinary alpha amino nitrogen, there was no detectable increase in the urinary copper excretion. In Wilson's disease as a result of a high protein diet an increased absorption of amino acids will occur and some of the excess amino acids may combine directly with the high tissue copper and an increase in the urinary excretion of copper will result. In normal subjects in whom tissue copper is not raised and in whom the renal threshold is not lowered no significant increase in the urinary excretion of copper will occur.

Although the association between urinary copper and amino acid excretion has been demonstrated there is no evidence that the copper and the amino acids are excreted as copper amino acid complexes, moreover, there are many other substances excreted in the urine other than amino acids to which copper could become bound. An attempt was made to determine the substances in the urine to which the copper was bound by zone electrophoresis experiments following the oral administration of radioactive copper. Several copper peaks were obtained when the experiment was run at the $\mathrm{pH}$ of the excreted urine but whether the copper was bound to certain specific amino acids or peptides was not entirely clear.

It has been suggested that in Wilson's disease there is a lowered renal threshold for amino acids and that this abnormality accounts for the finding of an increased excretion of amino acids in the urine $(4,8)$. The present finding that, following the administration of a high protein diet to patients with Wilson's disease, a greater quantity of amino acids was excreted in the urine than occurred in normal subjects could also be cited to support this hypothesis. However, consideration of the behaviour of individual amino acids, which is discussed more fully in the following paper (11), suggests that such a hypothesis may not explain all of the experimental findings.

The increased excretion of copper following cortisone was expected since it is known that cortisone increases the urinary excretion of amino acids (21). Mercurial diuretics and "Benemid," substances well known to have an action on the renal tubules, did not alter amino acid excretion and hence urinary copper excretion was not significantly increased. The increased urinary excretion of copper following the administration of BAL, or "Versene" intravenously was not associated with an increase in amino acid excretion, probably because both BAL and "Versene" are 
themselves substances which form a chelate with copper which is readily excreted in the urine.

"Versene" administered orally did not result in an increase in the urinary excretion of copper in patients with Wilson's disease. This observation is in contrast to recent findings in the treatment of lead poisoning (22) where an increased urinary excretion of lead followed the administration of "Versene" orally. The dose employed in the treatment of lead poisoning, however, was twice that employed in the present study.

Van Ravesteyn (19) has suggested that in normal subjects urinary copper excretion does not reflect dietary intake of copper. This study furnishes further evidence for this concept, since both normal subjects and patients with Wilson's disease, provided they were placed on a constant protein intake, did not show a significant increase in the urinary excretion of copper despite very large variations in copper in the diet. However, following the intravenous administration of trace amounts of radioactive copper it has been possible to demonstrate an increased urinary excretion of copper and a decreased fecal excretion compared with normal subjects.

There was no clear cut relation between the duration or severity of the disease process in patients with Wilson's disease and the degree of abnormality found in copper and amino acid metabolism. These biochemical findings were similarly unrelated to the degree of hepatic or neurological involvement or the presence of Kayser-Fleischer rings. The clinical improvement which sometimes appeared to follow the administration of various chelating agents was not related to the amount of copper excreted; the latter was similar in all types of the disease whether or not subsequent improvement occurred.

The finding that Wilson's disease is inherited in an autosomal recessive fashion (10) suggested the possibility that asymptomatic siblings might possess a biochemical abnormality. Uzman and Hood (23) have reported a family with Wilson's disease in whom examination of four asymptomatic siblings revealed an aminoaciduria. However, this family, in view of the large number of biochemically affected individuals described, is genetically atypical. It is also noteworthy that examination of 35 siblings in the present study failed to reveal an aminoaciduria in any individual. How- ever, an increased amino acid excretion was not found in one patient with undoubted Wilson's disease (11) and this observation suggests that an aminoaciduria may not be an early manifestation of the disease, and examination of asymptomatic siblings for abnormalities in copper metabolism should be preferentially undertaken. Investigation of the copper metabolism in some of the asymptomatic siblings has thus far failed to reveal any abnormalities.

As a hypothesis it is suggested that in Wilson's disease as a result of an increased absorption of copper this metal accumulates in the tissues and appears in the urine. If the deposition of copper in the liver becomes excessive cirrhosis may develop and, in an analogous fashion, accumulation of copper in the kidney may give rise to renal tubular damage. If this occurs an increased urinary excretion of amino acids, peptides and occasionally glucose will result.

\section{SUMMARY}

1. Copper and amino acid levels in serum and urine were determined in 17 patients with Wilson's disease and compared with a control group of patients with cirrhosis of the liver as well as with normal individuals.

2. Reduced copper levels in the serum and elevated urinary concentrations of copper were characteristic findings of the group with Wilson's disease. The presence of both abnormalities proved more characteristic of the disease than either one alone.

3. Markedly reduced levels of the serum copper protein, ceruloplasmin, were found in all cases of Wilson's disease, and represented the most specific biochemical abnormality found. The specificity of the enzymatic method for the determination of ceruloplasmin was demonstrated by procedures of zone electrophoresis.

4. A parallelism was demonstrated between the urinary copper and amino acid excretion in Wilson's disease. Increasing the amino acid excretion by increasing the protein intake, or by the administration of cortisone resulted in a parallel increase in the urinary excretion of copper.

\section{ACKNOWLEDGMENTS}

It is a pleasure to acknowledge our indebtedness to Doctor Houston Merritt, Doctor Theodore J. C. von 
Storch, Doctor Harold Wolff, and Doctor Morris Bender for having so kindly referred patients to us.

We wish to thank Mr. Charles Galati for expert technical assistance.

\section{REFERENCES}

1. Glazebrook, A. J., Wilson's disease. Edinburgh M. J., 1945, 52, 83.

2. Uzman, L., and Denny-Brown, D., Amino-aciduria in hepato-lenticular degeneration (Wilson's disease). Am. J. Med. Sc., 1948, 215, 599.

3. Denny-Brown, D., and Porter, H., The effect of BAL 2,3-dimercaptopropanol) on hepatolenticular degeneration (Wilson's disease). New England J: Med., 1951, 245, 917.

4. Cooper, A. M., Eckhardt, R. D., Faloon, W. W., and Davidson, C. S., Investigation of the aminoaciduria in Wilson's disease (hepatolenticular degeneration) : Demonstration of a defect in renal function. $\mathrm{J}$. Clin. Invest., 1950, 29, 265.

5. Bearn, A. G., and Kunkel, H. G., Biochemical abnormalities in Wilson's disease. J. Clin. Invest., 1952, 31, 616.

6. Moore, S., and Stein, W. H., Aminoaciduria in Wilson's disease. International Congress of Biochemistry, 2nd. Résumés des communications, Paris, Lons-le-Saunier, M. Declume, 1952, p. 367.

7. Scheinberg, I. H., and Gitlin, D., Deficiency of ceruloplasmin in patients with hepatolenticular degeneration (Wilson's disease). Science, 1952, 116, 484.

8. Matthews, W. B., Milne, M. D., and Bell, M., The metabolic disorder in hepato-lenticular degeneration. Quart. J. Med., 1952, 21, 425.

9. Holmberg, C. G., and Laurell, C.-B., Oxidase reactions in human plasma caused by coeruloplasmin. Scandinav. J. Clin. \& Lab. Invest., 1951, 3, 103.

10. Bearn, A. G., Genetic and biochemical aspects of Wilson's disease. Am. J. Med., 1953, 15, 442.

11. Stein, W. H., Bearn, A. G., and Moore, S., The amino acid content of the blood and urine in Wilson's disease. J. Clin. Invest., 1954, 33, 410.

12. Van Slyke, D. D., MacFadyen, D. A., and Hamilton, P. B., The gasometric determination of amino acids in urine by the ninhydrincarbon dioxide method. J. Biol. Chem., 1943, 150, 251.
13. Brand, E., Harris, M. M., and Biloon, S., Cystinuria. The excretion of a cystine complex which decomposes in the urine with the liberation of free cystine. J. Biol. Chem., 1930, 86, 315.

14. Nelson, N., A photometric adaptation of the Somogyi method for the determination of glucose. J. Biol. Chem., 1944, 153, 375.

15. Eden, A., and Green, H. H., Micro-determination of copper in biological material. Biochem. J., 1940, 34, 1202.

16. Kunkel, H. G., and Slater, R. J., Zone electrophoresis in a starch supporting medium. Proc. Soc. Exper. Biol. \& Med., 1952, 80, 42.

17. Kunkel; H. G., Ahrens, E. H., Jr., Eisenmenger, W. J., Bongiovanni, A. M., and Slater, R. J., Extreme hypergammaglobulinemia in young woman with liver disease of unknown etiology. J. Clin. Invest., 1951, 30, 654.

18. Lahey, M. E., Gubler, C. J., Cartwright, G. E., and Wintrobe, M. M., Studies on copper metabolism. VII. Blood copper in pregnancy and various pathologic states. J. Clin. Invest., 1953, 32, 329.

19. van Ravesteyn, A. H., Metabolism of copper in man. Acta med. Scandinav., 1944, 118, 163.

20. Gubler, C. J., Lahey, M. E., Cartwright, G. E., and Wintrobe, M. M., Studies on copper metabolism. IX. The transportation of copper in blood. J. Clin. Invest., 1953, 32, 405.

21. Bardawill, C. J., Gornall, A. G., Nishikawara, M., and Wightman, K. J. R., Studies on the behaviour of urinary amino nitrogen, serum alkaline phosphatase, and pseudo cholinesterase activity during ACTH therapy. Proc. Second Clinical ACTH Conference, J. R. Mote, ed., The Blakiston Co., Phila., 1951, 1, 264.

22. Sidbury, J. B., Jr., Bynum, J. C., and Fetz, L. L., Effect of chelating agent on urinary lead excretion. Comparison of oral and intravenous administration. Proc. Soc. Exper. Biol. \& Med., 1953, 82, 226.

23. Uzman, L. L., and Hood, B., The familial nature of the amino-aciduria of Wilson's disease (hepatolenticular degeneration). Am. J. Med. Sc., 1952, 223, 392. 